\title{
16. MOLECULAR AND STABLE ISOTOPE COMPOSITION OF HEADSPACE AND TOTAL HYDROCARBON GASES AT ODP LEG 104, SITES 642, 643, AND 644, VØRING PLATEAU, NORWEGIAN SEA ${ }^{1}$
}

\author{
Michael J. Whiticar and Eckhard Faber ${ }^{2}$
}

\begin{abstract}
Molecular and isotope compositions of headspace and total (free + sorbed) hydrocarbon gases from drilled cores of the three ODP Leg 104 Sites 642, 643, and 644 of the Vøring Plateau are used to characterize the origin and distribution of these gases in Holocene to Eocene sediments. Only minor amounts of methane were found in the headspace $(0.1$ to $<0.001 \mathrm{vol} \%$ ). Although methane through propane are present in all of the total gas samples, different origins account for the concentration and composition variations found.

Site 643 at the foot of the outer Vøring Plateau represents a geological setting with poor hydrocarbon generating potential, (sediments with low TOC and maturity overlying oceanic basement). Correspondingly, the total gas concentrations are low, typical for background gases (yield $C_{1-4}=31$ to $232 \mathrm{ppb}, \mathrm{C}_{1} / \mathrm{C}_{2+}=0.6$ to $4 ; \delta^{13} \mathrm{C}_{\mathrm{CH}_{4}}-22 \%$ to $-42 \%$ ) probably of a diagenetic origin.

Holocene to Eocene sediments, which overlie volcanic units, were drilled on the outer Vøring Plateau, at Holes 642B and D. Similar to Site 643 , these sediments possess a poor hydrocarbon generating potential. The total gas character (yield $C_{1-4}=20$ to $410 \mathrm{ppb} ; \mathrm{C}_{1} / \mathrm{C}_{2+}=1.7$ to $13.3 ; \delta^{13} \mathrm{C}_{\mathrm{CH}_{4}} \mathrm{ca} .-23 \%$ to $-40 \%$ ) again indicates a diagenetic origin, perhaps with the addition of some biogenic gas. The higher geothermal gradient and the underlying volcanics do not appear to have any influence on the gas geochemistry.

The free gas (Vacutainer ${ }^{\mathrm{TM}}$ ) in the sediments at Site 644 are dominated by biogenic gas $\left(\mathrm{C}_{1} / \mathrm{C}_{2+}>10^{4} ; \delta^{13} \mathrm{C}_{\mathrm{CH}_{4}}\right.$ $-77 \%$ ). Indications, in the total gas, of hydrocarbons with a thermogenic signature (yield $\mathrm{C}_{1-4}=121$ to $769 \mathrm{ppb}, \mathrm{C}_{1}$ ) $\mathrm{C}_{2+}=3$ to $8 ; \delta^{13} \mathrm{C}_{\mathrm{CH}_{4}}=-39 \%$ to $-71 \%$ ), could not be unequivocally confirmed as such. Alternatively, these gases may represent mixtures of diagenetic and biogenic gases.
\end{abstract}

\section{OBJECTIVES}

The ODP drilling transect of three sites across the Vøring Plateau provides a most interesting opportunity to examine the distribution and character of hydrocarbon gases in shallow $\mathrm{Ce}$ nozoic sediments from three geologically different, but adjacent settings in the Norwegian Sea:

1. Site 642-on the outer Vøring Plateau-Holocene to Eocene sediments underlain by a thick volcanic unit.

2. Site 643-foot of outer Vøring Plateau-Holocene to Eocene sediments directly overlying oceanic basement.

3. Site 644-in the inner Vøring Basin-Quaternary to upper Neogene sediments deposited over a subsiding continental crust.

The primary objectives of the shore-based geochemical studies at the BGR were to: (a) determine the character of sorbed hydrocarbon gases (for definitions see Analytical Program) in the sediments based on their molecular and isotope composition, (b) compare the character of the sorbed gas and the free gas, and (c) determine the relationship of the hydrocarbon gases to the diagenetic conditions. The relationship of the hydrocarbon gases to the isotope composition of the interstitial water is discussed in a companion report (Whiticar and Faber, this volume).

In particular, the three proximal, yet geologically different locations drilled offer the opportunity to directly compare the

\footnotetext{
${ }^{1}$ Eldholm, O., Thiede, J., Taylor, E., et al., 1989. Proc. ODP, Sci. Results, 104: College Station, TX (Ocean Drilling Program).

2 Federal Institute for Geosciences and Natural Resources (BGR), Stilleweg 2 , D-3000 Hannover, Federal Republic of Germany.
}

generation and accumulation of hydrocarbon gases in sediments where:

1. Site 643 , deep water-no thermogenic hydrocarbon potential is expected, i.e., immature, thin sediment cover over ocean basement.

2. Site 642 -hydrocarbon potential is poor, i.e., thin, young sediments overlying thick basalts.

3. Site 644-biogenic gas is known and thermogenic hydrocarbon potential is suspected, i.e., in a sedimentary basin with petroleum generation potential.

Hydrocarbon gases can be classified using the distinctive molecular and isotope signatures of the genetic gas types, such as biogenic, diagenetic, thermogenic, or late thermogenic. This gas classification scheme is routinely used to genetically characterize and correlate natural gases (Schoell, 1980). The classification relies not only on the ability to differentiate the primary gas types, but also to recognize secondary processes, such as mixing of different gas origins or microbial oxidation (Whiticar and Faber, 1986). In addition to reservoir gases, the classification scheme can be adapted to gases from drill wells, and near-surface sediments, where the hydrocarbon gas concentration is frequently much lower (Faber and Stahl, 1984).

Based on their geological settings, Sites 642 and 643 should represent valuable examples of the character and concentration of background hydrocarbon gases, i.e., light hydrocarbons which are common in most sediments, in lower concentrations, and which have a variable molecular and isotope composition. Background gases are frequently masked by the introduction of other gases from either biogenic or thermogenic hydrocarbon generating processes. Due to their lower gas contents, the origin of background gases is difficult to define. Although in-situ diagenetic reactions are one possible origin, input from allochtho- 
nous or altered gases (e.g., those altered by microbial oxidation) can not be eliminated in most locations. In contrast to Sites 642 and 643, the experiences of DSDP Site 341 (Leg 38) and industrial drilling in the Norwegian Sea predict that the concentration of hydrocarbon gases expected at Site 644 should be significantly above the low background level.

A further intention of this study was the comparison of sorbed gas data with free gas data of the various ODP Leg 104 sites. Previous investigations elsewhere have shown that biogenic gas is located primarily in the sediment intersticies (free gas), i.e., either dissolved in the pore water, present as a free gas, or as a gas hydrate. Analytical removal of this gas fraction is necessary to determine the character of the sorbed gases which are uninfluenced or masked by the biogenic signal. In addition, investigations have demonstrated that the effects of secondary alterations, such as hydrocarbon oxidation, are minimized in the sorbed gas fraction, where the gases seem to be protected from microbial assimilation (Faber et al., unpublished data).

\section{ANALYTICAL PROGRAM}

During the drilling of the ODP Leg 104 Holes 642B and D, $643 \mathrm{~A}$, and $644 \mathrm{~A}$ in the Norwegian Sea, 23 sediment samples, 2 gas pocket samples, and 32 pore-water samples were collected by the shipboard scientific party and air-freighted for analysis by the Stable Isotope Laboratory, BGR, Hannover, FRG. The sediments were stored frozen in metal cans until analyzed. The aliquots of the air-expressed interstitial waters and the gas pocket samples were injected into Vacutainers ${ }^{\mathrm{TM}}$ aboard ship and remained refrigerated until analyzed (Whiticar and Faber, 1987).

The various sample and analytical gas types, defined next, refer to the physical location of the gas in the sediment, and are different from the above-mentioned genetic gas types.

\section{Definitions of Analytical Gas Types}

Free-interstitial and loosely bound gases, measured (a) aboard ship by the gas extraction technique of Bernard et al., 1978; Kvenvolden and Redden, 1980 (see Kvenvolden and McDonald, this volume) and (b) at shore-based laboratories of the U.S. Geological Survey and Texas A\&M University (Kvenvolden et al., this volume).

Headspace-aliquot, taken by syringe, of gas volume in the cans over the thawed sediments.

Sorbed-loosely bound gas (free gas) removed first, then acid/vacuum extraction of bound gases in sediment according to the BGR method (Faber et al., unpublished data).

Total-combination of sorbed gas in sediments and the residual free gas (that which remains after any degassing during collection and subsequent opening of the cans). Identical to the sorbed gas method but without prior removal of free gas.

\section{Headspace and Free Gases, Procedural Details}

Samples of headspace gas from the canned sediments and from the two Vacutainer ${ }^{\mathrm{TM}}$ samples were analyzed by gas chromatography (GC) for molecular composition. The two Vacutainer samples and the single headspace Sample 104-644A-26H$3,10-16 \mathrm{~cm}$ had sufficient methane for $a^{13} \mathrm{C} /{ }^{12} \mathrm{C}$ determination.

Data for the free gas, dissolved-sulfate, and alkalinity measurements of the interstitial waters, used for comparison here, were determined by the shipboard party and are reported separately in this volume by Kvenvolden and McDonald (this volume) and Kvenvolden et al. (this volume).

\section{Sorbed and Total Gases, Procedural Details}

The wet sediment samples were weighed (200 to $300 \mathrm{~g}$ )* into a vacuum/acid degassing apparatus (Faber et al., unpublished data). Normally, the free gases are removed prior to this analysis by washing/sieving, and only the sorbed gases are analysed. Although this was our original intention, due to the limited sample quantity and their quality, it was necessary to collect the sorbed and free gases together (total gas). As shown by the headspace data, the hydrocarbons in the free gas fraction in our samples are low and contribute little methane and insignificant amounts of $\mathrm{C}_{2+}$ gases to the total. The total gases recovered were quantified by conventional analytical gas chromatography (GC).

Hydrocarbon concentrations are reported on a dry-weight basis (e.g., yield $C_{1} \mathrm{ppb}=$ grams $C_{1} / 10^{9}$ grams dry sediment). The compositional ratio $C_{1} / C_{2+}=C_{1} /\left(C_{2}+C_{2:}+C_{3}+C_{3}\right.$ : $\left.+\mathrm{i}, \mathrm{n}-\mathrm{C}_{4}\right)$, on a percent-volume basis, where $\mathrm{C}_{1}, \mathrm{C}_{2}, \mathrm{C}_{3}$, and $\mathrm{i}$, $\mathrm{n}-\mathrm{C}_{4}$ are n-alkanes and $\mathrm{C}_{2}, \mathrm{C}_{3}$ : are ethene and propene, respectively. Note that in Figure 1, $\mathrm{C}_{1} /$ sum $\mathrm{C}_{\mathrm{n}}=\mathrm{C}_{1} / \mathrm{C}_{1-4}$.

In preparation for isotope measurements, the hydrocarbon gases were partitioned by $\mathrm{GC}$, then combusted over $\mathrm{CuO}\left(880^{\circ} \mathrm{C}\right)$ and the resultant $\mathrm{CO}_{2}$ and $\mathrm{H}_{2} \mathrm{O}$ collected. ${ }^{13} \mathrm{C} /{ }^{12} \mathrm{C}$ ratios of methane and in a few cases ethane, were measured as $\mathrm{CO}_{2}$ on an isotope ratio mass spectrometer. Sufficient combustion water was available from three methane samples for reduction to $\mathrm{H}_{2}$ on zinc and a $\mathrm{D} / \mathrm{H}$ ratio measurement.

The amounts of hydrocarbons available for combustion were, in general, extremely low, sometimes less than $1 \mu \mathrm{L}$. The carbon isotope measurements of methane with low quantities (below ca. $1 \mu \mathrm{L}$ hydrocarbon gas), and ethane measurements have a somewhat larger analytical uncertainty.

The stable isotope data are presented in the usual $\delta$-notation:

$$
\delta R_{A}(\% 0)=\left(\frac{R_{A} / R_{B \text {-sample }}}{R_{A} / R_{B \text {-standard }}}-1\right) \times 10^{3}
$$

where $R_{A} / R_{B}$ is ${ }^{13} \mathrm{C} /{ }^{12} \mathrm{C}$ and $\mathrm{D} / \mathrm{H}$ relative to the $\mathrm{PDB}$ and SMOW standards, respectively.

\section{RESULTS AND DISCUSSION}

Despite the sometimes difficult coring conditions encountered, adequate samples was generally available for a GC of the headspace gas, acid/vacuum degassing, quantitative GC of the total gas, and $a^{13} \mathrm{C} /{ }^{12} \mathrm{C}$ determination of the methane. However, as mentioned, some uncertainty in the data is expected from the samples of poorer quality.

\section{Headspace Samples}

In the headspace samples, the free gases from the sediments are strongly diluted by atmospheric air, probably introduced in the can during sampling. Methane is essentially the only hydrocarbon present in notable amounts, and constitutes only 0.0004 to $0.1 \%$ of the gas in the headspace (Table 1). Only trace amounts of ethane are recorded.

The only ${ }^{13} \mathrm{C} /{ }^{12} \mathrm{C}$ measurement of methane from a headspace Sample, 104-644A-26H-3, 10-16 cm, is $-68.5 \%$, which, despite the low methane content, clearly indicates a gas of biogenic origin (Whiticar et al., 1986). The two Vacutainer Sections $104-644 \mathrm{~A}-14-2,24 \mathrm{~cm}$ and $-644 \mathrm{~A}-16-2,15 \mathrm{~cm}$, on the other hand, are rich in methane $(55.6 \%$ and $66.9 \%$, Table 1$)$, with

*Note: due to the slurry nature of the original sample material, the actual weight of sediment/drill-fluid available for the degassing was generally around 50 $\mathrm{g}$ dry weight (min. $16.4 \mathrm{~g}$, max. $138.0 \mathrm{~g}$ ), the remainder presumably being water. 
Table 1. Hydrocarbon composition of headspace and Vacutainer gases of the samples from Sites 642, 643 , and 644.

\begin{tabular}{|c|c|c|c|c|c|c|c|c|}
\hline \multirow[b]{2}{*}{ Rec\# } & \multirow[b]{2}{*}{ Sample 104} & \multirow{2}{*}{$\begin{array}{l}\text { Depth } \\
\text { (mbsf) }\end{array}$} & \multirow{2}{*}{$\begin{array}{c}\% \text { gas } \\
\mathrm{CH}_{4} \text { (\%tot) }\end{array}$} & \multicolumn{2}{|c|}{$\left\langle-\sigma_{0}\right.$ hc $->>$} & \multirow[b]{2}{*}{$\delta^{13} \mathrm{C}_{\mathrm{CH}_{4}}$} & \multirow[b]{2}{*}{$\delta \mathrm{D}_{\mathrm{CH}_{4}}$} & \multirow[b]{2}{*}{$\delta^{13} \mathrm{C}_{\mathrm{CO}_{2}}$} \\
\hline & & & & $\mathrm{CH}_{4}(\%)$ & $\mathrm{C}_{2} \mathrm{H}_{6}(\%)$ & & & \\
\hline 1 & $642 \mathrm{~B}-1-03,0-014$ & 3.07 & - & - & - & - & - & - \\
\hline 2 & $642 \mathrm{~B}-7 \mathrm{H}-4,119-133$ & 53.16 & 0.101 & 100.0 & - & - & - & - \\
\hline 3 & 642B-10X-6,0-14 & 83.47 & .000 & 100.0 & - & - & - & - \\
\hline 4 & $642 \mathrm{~B}-13 \mathrm{H}-4,120-134$ & 109.97 & .001 & 100.0 & 0.00 & - & - & - \\
\hline 5 & $642 \mathrm{~B}-19 \mathrm{H}-4,117-131$ & 163.44 & .001 & 100.0 & .00 & - & - & - \\
\hline 6 & $642 \mathrm{~B}-25 \mathrm{H}-4,116-130$ & 218.83 & .012 & 100.0 & .00 & - & - & - \\
\hline 7 & $642 \mathrm{D}-4-5,120-134$ & 216.47 & .002 & 100.0 & .00 & - & - & - \\
\hline 8 & $643 \mathrm{~A}-5 \mathrm{H}-2,73-79$ & 35.06 & .001 & 100.0 & - & - & - & - \\
\hline 9 & $643 A-11-5,85-91$ & 97.68 & - & - & 一 & - & - & - \\
\hline 10 & $643 \mathrm{~A}-16-6,110-116$ & 146.93 & - & - & - & - & - & - \\
\hline 11 & $643 \mathrm{~A}-23-4,5-11$ & 209.68 & .001 & 100.0 & .00 & - & - & - \\
\hline 12 & $643 \mathrm{~A}-29-3,140-145$ & 268,33 & .000 & 100.0 & - & - & - & - \\
\hline 13 & $643 \mathrm{~A}-35-1,101-107$ & 323.74 & - & - & - & - & - & - \\
\hline 14 & $643 A-41-C C, 10-16$ & 390.23 & .000 & 100.0 & - & - & - & - \\
\hline 15 & $643 \mathrm{~A}-47-4,140-146$ & 445.03 & - & - & - & - & - & - \\
\hline 16 & $643 A-53 X-4,10-16$ & 501.63 & .001 & 100.0 & .00 & - & - & - \\
\hline 17 & $644 \mathrm{~A}-2 \mathrm{H}-4,0-6$ & 13.73 & - & - & - & - & - & - \\
\hline 18 & $644 \mathrm{~A}-9-5,91-97$ & 80.14 & .013 & 100.0 & - & - & - & - \\
\hline 19 & $644 \mathrm{~A}-14-2,27-34$ & 122.50 & - & - & - & - & - & - \\
\hline 20 & $644 \mathrm{~A}-16 \mathrm{H}-2,7-13$ & 141.30 & .005 & 100.0 & - & - & - & - \\
\hline 21 & $644 \mathrm{~A}-20-4,1-6$ & 182.24 & .007 & 100.0 & - & - & - & - \\
\hline 22 & $644 \mathrm{~A}-26 \mathrm{H}-3,10-16$ & 213.63 & .049 & 100.0 & .00 & -68.5 & - & - \\
\hline 23 & $644 \mathrm{~A}-32 \mathrm{H}-3,10-17$ & 241.23 & .034 & 100.0 & .00 & - & - & - \\
\hline 24 & 644A-14-2, 24GAS & 122.44 & 55.599 & 100.0 & .01 & -77.7 & -264.0 & -16.3 \\
\hline 25 & $644 \mathrm{~A}-16-2,15 \mathrm{GAS}$ & 141.35 & 66.859 & 100.0 & .01 & -76.4 & -270.0 & -12.5 \\
\hline
\end{tabular}

only trace amounts of higher hydrocarbons detected $(0.01 \%)$. The $\delta^{13} \mathrm{C}_{\mathrm{CH}_{4}}$ of Vacutainers are $-77.7 \%$ and $-76.4 \%$ (Table 1 ), and the corresponding $\delta \mathrm{D}_{\mathrm{CH}_{4}}$ measurements are $-264 \%$ and $-270 \%$, respectively. The molecular and isotope data indicate that these gases, too, are of a biogenic origin.

\section{Total Gas Samples}

\section{Site 643}

This hole represents the geological situation with poor hydrocarbon potential. This is reflected by the low total hydrocarbon gas yields (sum $\mathrm{C}_{1-4}$ ) of 30 to $50 \mathrm{ppb}$ (dry weight basis, Table 2). Slightly higher yields (182 to $233 \mathrm{ppb}$ ) are measured near the surface, but they are still significantly lower than the maximum of $769 \mathrm{ppb}$ found at Hole 644A. The individual $C_{1}$ to $C_{3}$ n-alkanes covary with depth, as seen in Figure 1, giving a wetness ratio $\left(C_{1} /\right.$ sum $\left.C_{1-4}\right)$ of about 0.6 . Butane and pentane homologes are also present in amounts as much as $40 \mathrm{ppb}$.

The carbon isotope measurements of methane found in low quantities (below ca. $1 \mu \mathrm{L} \mathrm{C}$ ), are $\delta^{13} \mathrm{C}_{\mathrm{CH}_{4}}$ values of $-21.5 \%$, and $-23.5 \%$ (Table 3 ). The two samples nearest the surface, contain more methane, and have $\delta^{13} \mathrm{C}_{\mathrm{CH}_{4}}$ values of $-41.6 \%$ and $-27.1 \%$.

Dissolved sulfate is being continually removed from the interstitial water by microbial oxidation (e.g., of organic matter), but in the interval sampled for total gases, the sulfate level remained too high to permit the onset of methanogenesis. This lack of sulfate exhaustion is a consequence of the rather low TOC (total organic carbon) contents in these sediments, and is substantiated by the extremely low free and total gas concentrations.

Nevertheless, it is most interesting to note that in these sediments with low hydrocarbon potential there are still measurable, albeit minor, amounts of hydrocarbons present. These hydrocarbon concentrations can be regarded as background hydrocarbon levels for this sector of the Norwegian Sea, and, as will be discussed, are possibly the result of diagenetic generation of hydrocarbons. As explained below, the slightly higher yields near the surface could be due to minor biogenic gas production in conjunction with the more labile organic matter. The absence of methane in the headspace belies any post-sampling effects.

\section{Site 642}

The hydrocarbon concentration of the total gas fraction of the samples at Holes 642B and 642D are slightly higher than at Hole $643 \mathrm{~A}$ and vary from a minimum of $19 \mathrm{ppb}$ to a maximum of $382 \mathrm{ppb}$ (sum $\mathrm{C}_{1-4}$ ). The concentrations of the individual nalkanes vary slightly with depth (Fig. 1), while the amount of methane tends to decrease from the surface. Similar to Hole $643 \mathrm{~A}$, the iso- and n-butane are both present with yields around $20 \mathrm{ppb}$ (Table 3). The molecular composition $\left(\mathrm{C}_{1} /\right.$ sum $\left.\mathrm{C}_{1-4}\right)$ of the hydrocarbon gases varies with depth between 0.72 and 0.93 (Fig. 1), except the single sample at Hole 642D that had comparatively less methane $\left(C_{1} /\right.$ sum $\left.C_{1-4}=0.63\right)$.

The $\delta^{13} \mathrm{C}_{\mathrm{CH}_{4}}$ values of the samples with higher methane contents are about $-37 \%$ (Fig. 1, Table 3), whereas the samples with low hydrocarbon yields are ca. $-23 \%$, similar to the background gases at Hole 643A. The single Section 104-642B-1H-3, $14 \mathrm{~cm}$, for which a D/H measurement was possible, has a $\delta \mathrm{D}_{\mathrm{CH}_{4}}$ of $-165 \%$.

The dissolved sulfate content at Site 642 decreases with depth but, remains at a concentration too high to permit methanogenesis, despite the slightly higher TOC than at Hole 643A.

The gas geochemistry at Site 642 provides no indication of early thermal maturation of the organic matter in the sediments covering the volcanic basement at this drill site. The stronger geothermal gradient of 0.08 to $0.085^{\circ} \mathrm{C} / \mathrm{m}$ in this region than, for example, at Site 644 in the inner Vøring Basin $\left(0.067^{\circ} \mathrm{C} / \mathrm{m}\right.$, E. Taylor et al., unpublished data) appears to have no effect on hydrocarbon generation.

\section{Site 644}

The geochemical situation at Site 644 is different from those at the more westerly sites. The total hydrocarbon gas yields with a maximum of $769 \mathrm{ppb}$, are in some cases significantly higher than at Holes 642B and 642D and in particular at Site 643A (Table 2). The variability in yield is recorded in Figure 1 with a rough trend to lower concentrations of the individual n-alkanes 
Table 2. Total hydrocarbon gas yields of samples from Sites 642,643 , and 644 .

\begin{tabular}{|c|c|c|c|c|c|c|c|c|c|c|}
\hline \multirow[b]{2}{*}{ Rec\# } & \multirow[b]{2}{*}{ Sample 104- } & \multirow{2}{*}{$\begin{array}{l}\text { Depth } \\
\text { (mbsf) }\end{array}$} & \multicolumn{8}{|c|}{$<-$ Hydrocarbon yield (ppb wt) $->$} \\
\hline & & & $\mathrm{CH}_{4}$ & $\mathrm{C}_{2} \mathrm{H}_{4}$ & $\mathrm{C}_{2} \mathrm{H}_{6}$ & $\mathrm{C}_{3} \mathrm{H}_{6}$ & $\mathrm{C}_{3} \mathrm{H}_{8}$ & $\mathrm{i}-\mathrm{C}_{4}$ & $\mathrm{n}-\mathrm{C}_{4}$ & sum $C_{1-4}$ \\
\hline 1 & $642 \mathrm{~B}-1-3,0-14$ & 3 & 291 & 0 & 37 & 28 & 21 & 16 & 17 & 410 \\
\hline 2 & $642 \mathrm{~B}-7 \mathrm{H}-4,119-133$ & 53 & 43 & 0 & 14 & 0 & 9 & 0 & 9 & 75 \\
\hline 3 & $642 \mathrm{~B}-10 \mathrm{X}-6,0-14$ & 83 & 235 & 0 & 15 & 0 & 8 & 0 & 25 & 282 \\
\hline 4 & $642 \mathrm{~B}-13 \mathrm{H}-4,120-134$ & 110 & 159 & 0 & 48 & 0 & 66 & 24 & 18 & 316 \\
\hline 5 & $642 \mathrm{~B}-19 \mathrm{H}-4,117-131$ & 163 & 130 & 0 & 48 & 0 & 36 & 24 & 19 & 256 \\
\hline 6 & $642 \mathrm{~B}-25 \mathrm{H}-4,116-130$ & 219 & 16 & 0 & 3 & 0 & 0 & 0 & 0 & 20 \\
\hline 7 & $642 \mathrm{D}-4-5,120-134$ & 216 & 23 & 0 & 6 & 15 & 13 & 0 & 0 & 57 \\
\hline 8 & $643 \mathrm{~A}-5 \mathrm{H}-2,73-79$ & 36 & 95 & 0 & 28 & 16 & 22 & 22 & 15 & 199 \\
\hline 9 & $643 \mathrm{~A}-11-5,85-91$ & 98 & 100 & 0 & 76 & 0 & 57 & 0 & 0 & 232 \\
\hline 10 & $643 A-16-6,110-116$ & 147 & 33 & 0 & 22 & 32 & 11 & 18 & 24 & 139 \\
\hline 11 & $643 \mathrm{~A}-23-4,05-11$ & 210 & 16 & 0 & 7 & 0 & 8 & 0 & 17 & 47 \\
\hline 12 & $643 \mathrm{~A}-29-3,140-146$ & 268 & 14 & 0 & 6 & 5 & 5 & 4 & 8 & 41 \\
\hline 13 & $643 \mathrm{~A}-35-1,101-107$ & 324 & 45 & 18 & 21 & 24 & 19 & 40 & 35 & 203 \\
\hline 14 & $643 A-41-C C, 10-16$ & 390 & 28 & 23 & 17 & 23 & 13 & 25 & 13 & 141 \\
\hline 15 & $643 \mathrm{~A}-47-4,140-146$ & 445 & 25 & 5 & 10 & 0 & 9 & 0 & 0 & 49 \\
\hline 16 & $643 \mathrm{~A}-53 \mathrm{X}-4,10-16$ & 502 & 20 & 0 & 8 & 0 & 2 & 0 & 0 & 31 \\
\hline 17 & $644 \mathrm{~A}-2 \mathrm{H}-4,00-06$ & 14 & 414 & 13 & 97 & 0 & 73 & 45 & 46 & 689 \\
\hline 18 & $644 \mathrm{~A}-9-5,91-97$ & 80 & 46 & 0 & 105 & 0 & 94 & 54 & 53 & 769 \\
\hline 19 & $644 \mathrm{~A}-14-2,27-34$ & 123 & 152 & 0 & 50 & 0 & 33 & 13 & 28 & 277 \\
\hline 20 & $644 \mathrm{~A}-16 \mathrm{H}-2,07-13$ & 141 & 424 & 0 & 65 & 0 & 49 & 31 & 37 & 605 \\
\hline 21 & $644 \mathrm{~A}-20-4,02-06$ & 182 & 128 & 0 & 29 & 0 & 20 & 0 & 0 & 176 \\
\hline 22 & $644 \mathrm{~A}-26 \mathrm{H}-3,10-16$ & 214 & 88 & 0 & 19 & 0 & 14 & 0 & 0 & 121 \\
\hline 23 & $644 \mathrm{~A}-32 \mathrm{H}-3,10-16$ & 241 & 280 & 0 & 24 & 20 & 18 & 17 & 14 & 373 \\
\hline
\end{tabular}

at greater depth. This is also seen at Holes 642B, 642D, and $643 \mathrm{~A}$. In the upper portion of the core, the $C_{1} /$ sum $C_{1-4}$ is 0.75 to 0.79 . Below $140 \mathrm{mbsf}$ down to total depth (TD) there is a sharp compositional break to more methane-rich values of 0.85 to 0.89 (Fig. 1).

This compositional break near $140 \mathrm{mbsf}$ is also reflected in the carbon isotope values. The upper section of the Hole 644 has $\delta^{13} \mathrm{C}_{\mathrm{CH}_{4}}$ values of $-38.5 \%$ to $-43.0 \%$, which are comparable with the ratios measured for methane present in higher concentrations at Holes 642B and 642D.

Below about 140 mbsf the methane shifts to more ${ }^{13} \mathrm{C}$-depleted carbon isotope values of $-49.0 \%$ to $-71.4 \%$. This carbon isotope composition indicates that methanogenesis is the dominant origin of the methane at greater depth (Whiticar et al., 1986). This interpretation is consistent with the distribution of dissolved sulfate. In the upper portion of the hole, dissolved sulfate concentrations decrease rapidly with depth (see Kvenvolden and McDonald, this volume) but are sufficient to inhibit methanogenesis. Dissolved sulfate is exhausted below $100 \mathrm{mbsf}$, which corresponds to the onset of methanogenesis. Similarly, Kvenvolden et al. (this volume) report high methane concentrations in the free gas fraction, dependent on the presence or absence of dissolved sulfate. They interpret this free gas to be of biogenic origin with regard to the $\delta^{13} \mathrm{C}_{\mathrm{CH}_{4}}$ of $-62 \%$ to $-90 \%$. In the samples received at the BGR, slightly more methane is present in the headspace samples at Site 644 than at the other two sites ( 0.05 percent-volume max.), but in comparison with the results of Kvenvolden et al. (this volume), severe loss of gas is evident for all the samples using this sampling technique. A single $\delta^{13} \mathrm{C}_{\mathrm{CH}_{4}}$ value of $-68.5 \%$ was measured for the headspace at 213.6 mbsf (Site 644), which confirms the biogenic origin of the gas.

\section{Genetic Classification of Hydrocarbon Gases}

The wide range of molecular and isotope compositions and of hydrocarbon concentrations at the three ODP Leg 104 sites reveal the presence of several gas types. In some cases a genetic origin can be assigned, e.g., biogenic gases, whereas for many of the other samples the origin designation is ambiguous, particularly among the low concentration background gases. The primary genetic gas types considered here are:
1. Biogenic-higher yields in total (or free) gas fraction, predominantly methane depleted in ${ }^{13} \mathrm{C}\left(\delta^{13} \mathrm{C}_{\mathrm{CH}_{4}}\right.$ range: $-60 \%$ to $-90 \%$ )

2. Thermogenic-moderate yields in total (or sorbed) gas fraction, rich in higher homologes, $\left(\delta^{13} \mathrm{C}_{\mathrm{CH}_{4}}\right.$ range: $-50 \%$ to $-30 \% 0$ ).

3. Diagenetic-very low to low yields, varying proportions of higher homologues, $\left(\delta^{13} \mathrm{C}_{\mathrm{CH}_{4}}\right.$ ca. $-22 \%$ ).

Biogenic gases are identified at Hole 644B, in headspace and total gas samples, and in free gas samples (Kvenvolden et al., this volume) as mentioned before. This finding was expected because biogenic gas had been reported by Morris (1976) at the geologically comparable DSDP Leg 38 , Site $341\left(C_{1} /\left(C_{2}+C_{3}\right)\right.$ ca. $10^{4}, \delta^{13} \mathrm{C}_{\mathrm{CH}_{4}}$ ca. $-80 \%$ ). A severe drill rig blow-out also occurred at a location adjacent to this region, which is believed to be the result of an excessive biogenic methane pressure. No light hydrocarbons were reported at the other sites of DSDP Leg 38.

The two Vacutainer samples and the headspace Core 104644A-26 contain biogenic methane, which is interpreted to have been formed by methanogenic $\mathrm{CO}_{2}$ reduction pathway as opposed to methyl-type fermentation. This is founded, in part, on the combination of the $\delta^{13} \mathrm{C}_{\mathrm{CH}_{4}}$ and $\delta \mathrm{D}_{\mathrm{CH}_{4}}$ values as shown in Figure 2 (Whiticar et al., 1986). The combination of these methane isotope values with those of the $\delta^{13} \mathrm{C}_{\mathrm{ECO}}$ and $\delta \mathrm{D}_{\mathrm{H}_{2} 0}$ in the companion paper (see Whiticar and Faber, this volume), confirm this interpretation.

With the exception of the samples at $36 \mathrm{mbsf}$ and $98 \mathrm{mbsf}$, the gases at Hole 643A are representative examples of background gases, ie., sum $\mathrm{C}_{1-4}$ hydrocarbon generally yields less than $100 \mathrm{ppb}$. Similarly, at Holes $642 \mathrm{~B}$ and D the samples at 53 mbsf, 216 mbsf, and 219 mbsf have low total yields. The gas yields of the remaining samples, including those at Hole 644A, are higher than normally expected for background gases. A characteristic of the low yield background gases is their enrichment of the $\mathrm{C}_{2+}$ hydrocarbons relative to methane, and in some cases, the presence of significant amounts of unsaturated hydrocarbons (up to $29 \%$, Table 3). Another diagnostic feature is methane relatively enriched in ${ }^{13} \mathrm{C}$ (see above). These background gases are most likely autochthonous, and products of the diagenetic decomposition of organic matter in these sediments, either 


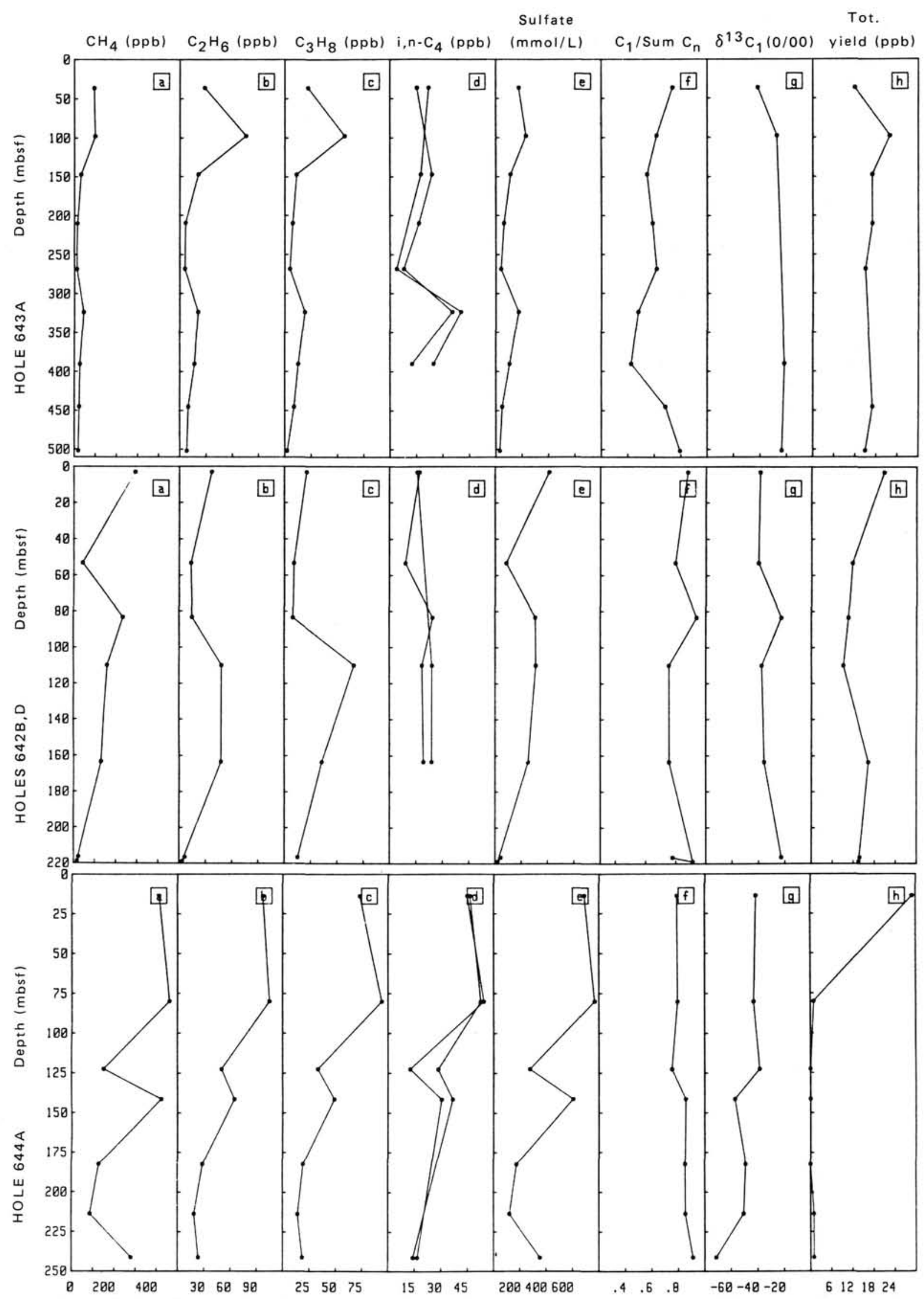

Figure 1. Distribution of total hydrocarbon gas composition at Holes 642B, 642D, 643A, and 644A. Yields are expressed as a weight of gas relative to weight of dry sediment. 
Table 3. Relative hydrocarbon percentage and isotope composition of hydrocarbon gas yields of samples from Sites 642,643 , and 644 .

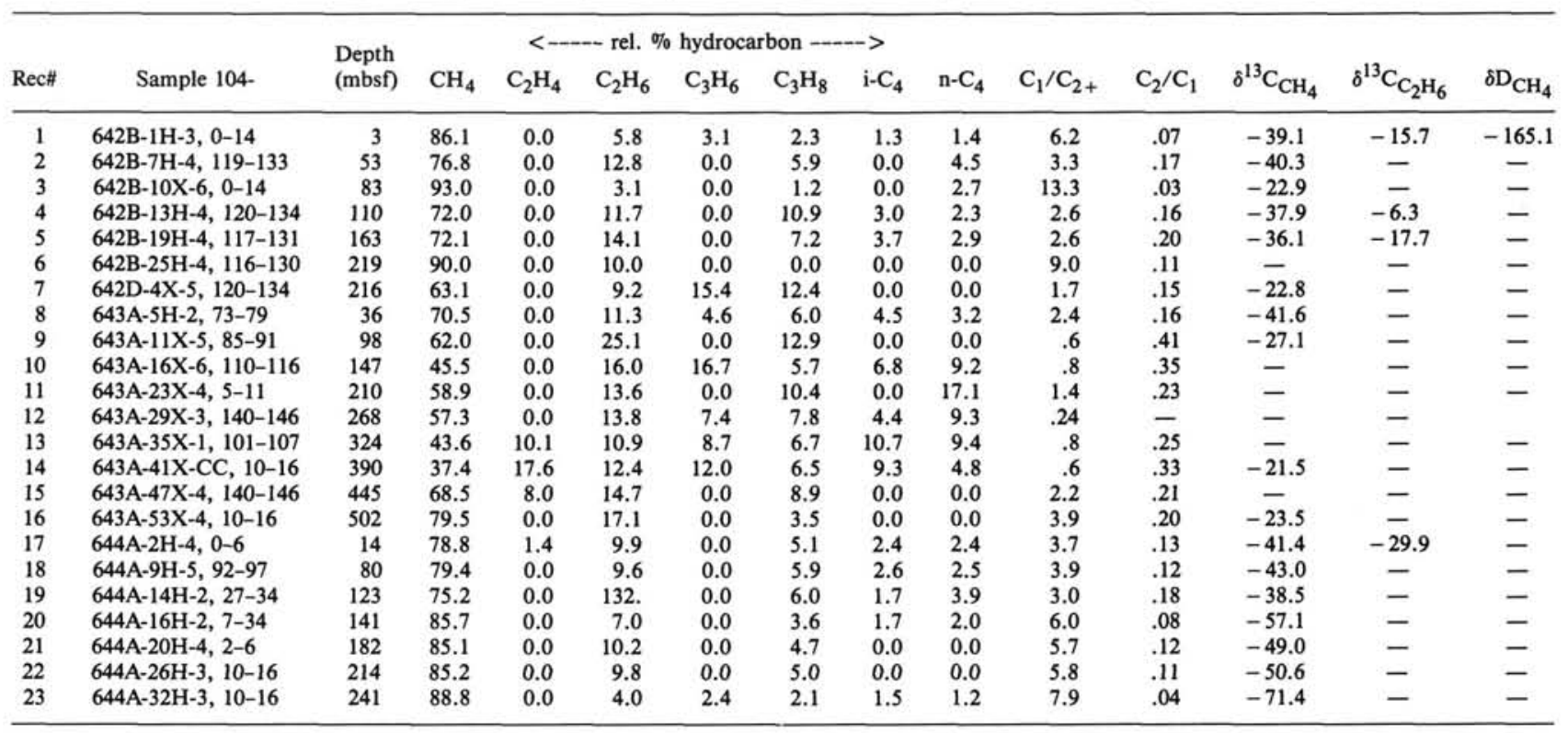

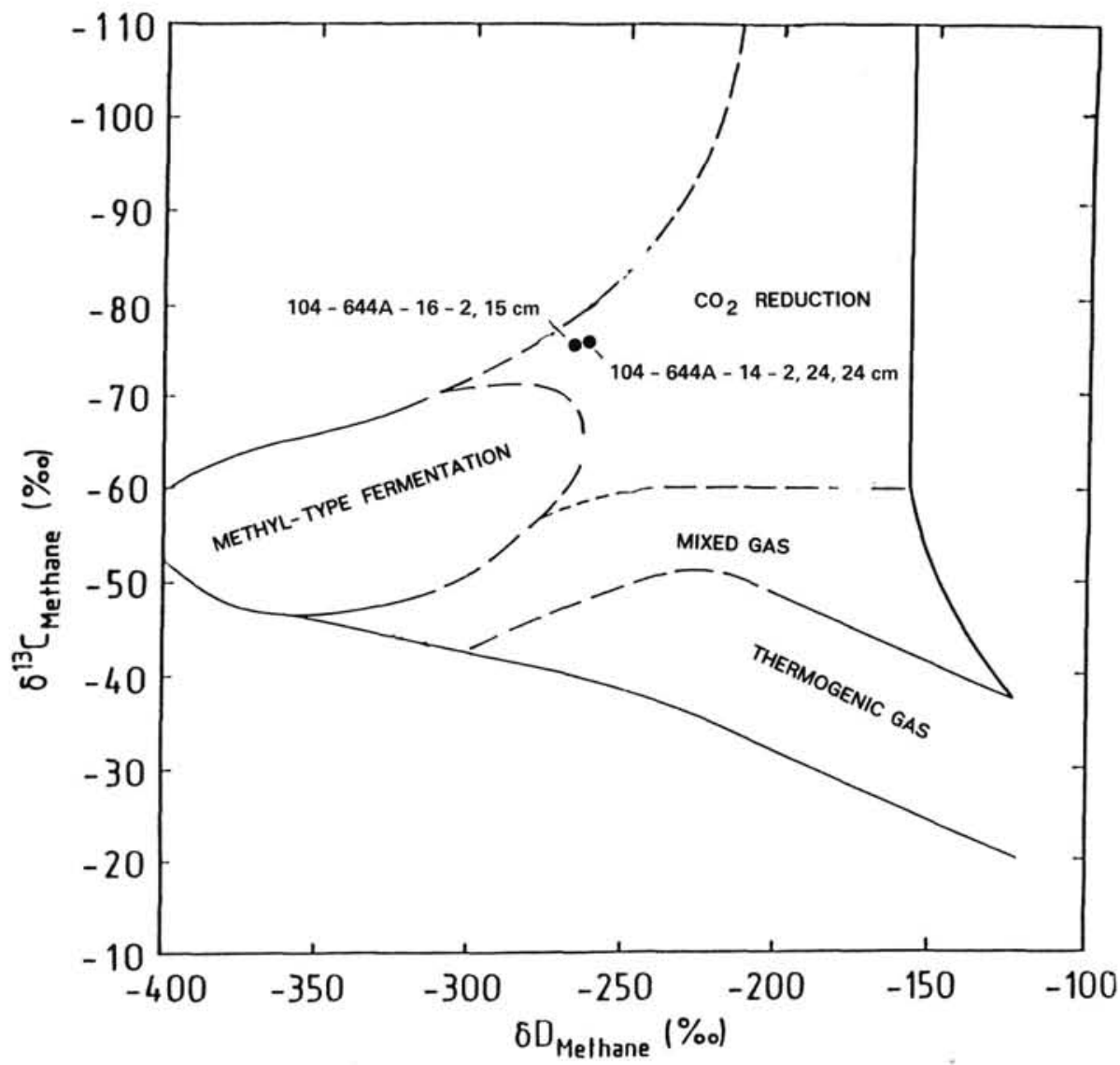

Figure 2. Cross plot of $\delta \mathrm{D}_{\mathrm{CH}_{4}}$ vs. $\delta^{13} \mathrm{C}_{\mathrm{CH}_{4}}$ showing the form of methanogenesis of the biogenic gas in the Vacutainers.

by chemical or biosynthetic processes. The $\delta^{13} \mathrm{C}_{\mathrm{CH}_{4}}$ is similar to that of the sediment kerogen at DSDP Site $341\left(\delta^{13} \mathrm{C}_{\mathrm{org}}=\right.$ $-22 \%$ to $-25 \%$, Erdman and Schorno, 1976). Provided that there is a homogeneous isotope distribution within the kerogen, the low isotope separation seen between the kerogen and hydro- carbon gas generated implies only a minor isotope effect associated with the carbon transfer from kerogen to hydrocarbon gas. This diagenetic gas type is probably present in most, if not all, of the ODP Leg 104 samples, including those of Hole 644A, but is frequently masked by the admixture of other gases. With 
regard to the classification diagram of $\delta^{13} \mathrm{C}_{\mathrm{CH}_{4}}$ vs. $\mathrm{C}_{1} / \mathrm{C}_{2+}$ (Fig. 3 , modified from Bernard, 1980), the composition of several of the hydrocarbon gases at Holes 642B and D (samples 1, 2, 4, 5, Tables 2, 3, Fig. 3) and Hole 644A (samples 17, 18, 19, Tables 2, 3 , Fig. 3) suggest a thermogenic origin, if they were considered only in isolation. Values of $\mathrm{C}_{1} / \mathrm{C}_{2+}$ of ca. 3 and $\delta^{13} \mathrm{C}_{\mathrm{CH}_{4}}$ around $-39 \%$ to $-42 \%$ are typical for these gases. They generally have yields above the background level, but are lower relative to the yields found in surface sediments over known petroliferous regions, e.g., North Sea (Faber and Stahl, 1984). Although such a thermogenic source can not be eliminated for some of these ambiguous samples, there is auxillary evidence indicating that these are mixed gases and are not primary.

To demonstrate the possibility of mixed gas origin, the $\mathrm{C}_{1} /$ $\mathrm{C}_{2+}$ and $\delta^{13} \mathrm{C}_{\mathrm{CH}_{4}}$ values of the total gases from the three ODP sites are plotted together in Figure 4. The two-component mixing line shown in Figure 4 is calculated by taking the respective values of the two end members:

1. Diagenetic/background gas $\left(\mathrm{C}_{1} / \mathrm{C}_{2+}=2.0, \delta^{13} \mathrm{C}_{\mathrm{CH}_{4}}=\right.$ $-22 \% 0$ )

2. Biogenic gas $\left(\mathrm{C}_{1} / \mathrm{C}_{2+}=10^{4}, \delta^{13} \mathrm{C}_{\mathrm{CH}_{4}}=-80 \% 0\right)$.

The gases which lie within the zone of thermogenic gases can be explained by the admixture of $20 \%$ to $25 \%$ biogenic gas with the diagenetic gas. This mixing trend is particularly apparent for the gases at Hole $644 \mathrm{~A}$. It could be argued that the gases which fall within the thermogenic zone only coincidentally lie on this mixing line between biogenic and diagenetic gases. For example, at Holes 642B, 642D, and 643A no clear biogenic component is observed, nor is major methanogenesis by $\mathrm{CO}_{2} \mathrm{re}-$ duction expected in these sediments due to the presence of sulfate. Some minor methanogenesis by noncompetitive methyl- fermenters may be an explanation. Alternatively, these gases may also be of diagenetic origin, distinct in character from those described at Hole 643A.

Further lines of evidence against a thermogenic classification of these gases are the presence of significant amounts of unsaturated hydrocarbons, and the carbon isotope ratio of ethane. The three $\delta^{13} \mathrm{C}_{\mathrm{C}_{2} \mathrm{H}_{6}}$ measurements at Site 642 are far too enriched in ${ }^{13} \mathrm{C}$ relative to those expected for thermogenic hydrocarbons. For the $\delta^{13} \mathrm{C}_{\mathrm{CH}_{4}}$ values of $-36 \%$ to $-39 \%$, the corresponding $\delta^{13} \mathrm{C}_{\mathrm{C}_{2} \mathrm{H}_{6}}$ should lie around $-27 \%$ to $-30 \%$, provided both are of the same thermogenic origin. A single sample at Site 644 (Sample 104-644A-2H-4, 0-6 cm) tentatively fits within such a thermogenic framework with $\delta^{13} \mathrm{C}_{\mathrm{CH}_{4}}$ values of $-41.4 \%$ and $\delta^{13} \mathrm{C}_{\mathrm{C}_{2} \mathrm{H}_{6}}$ values of $-29.9 \%$. Additional, more reliable ${ }^{13} \mathrm{C}_{\mathrm{C}_{2} \mathrm{H}_{6}}$ are required to confirm such an interpretation. If this gas were thermogenic, then the estimated maturity of the source kerogen would correspond to ca. 1.1 to $1.2 \% \mathrm{Ro}_{\text {equivalent }}$ based on the $\delta^{13} \mathrm{C}_{\mathrm{CH}_{4}}$ and $\delta^{13} \mathrm{C}_{\mathrm{C}_{2} \mathrm{H}_{6}}$ measurements. Considering that only immature sections are encountered at Hole 644A, a thermogenic interpretation would necessitate that this gas be allochtonous, migrating from a more mature, and likely deeper, source.

The single total gas (Sample 104-642B-1-3, 0-14 cm) for which $\delta \mathrm{D}_{\mathrm{CH}_{4}}$ is available, had a higher hydrocarbon yield of 382 $\mathrm{ppb}$ and falls in the zone of thermogenic gas.

\section{CONCLUSIONS}

Regardless of structural, or geochemical situation, methane, ethane and propane, and, in most cases, butanes and unsaturated hydrocarbons are present in the sediments of all three ODP 104 sites. With the methods available, these could be quantified, and despite the low gas contents available, isotope measurements could be conducted on most of the samples.

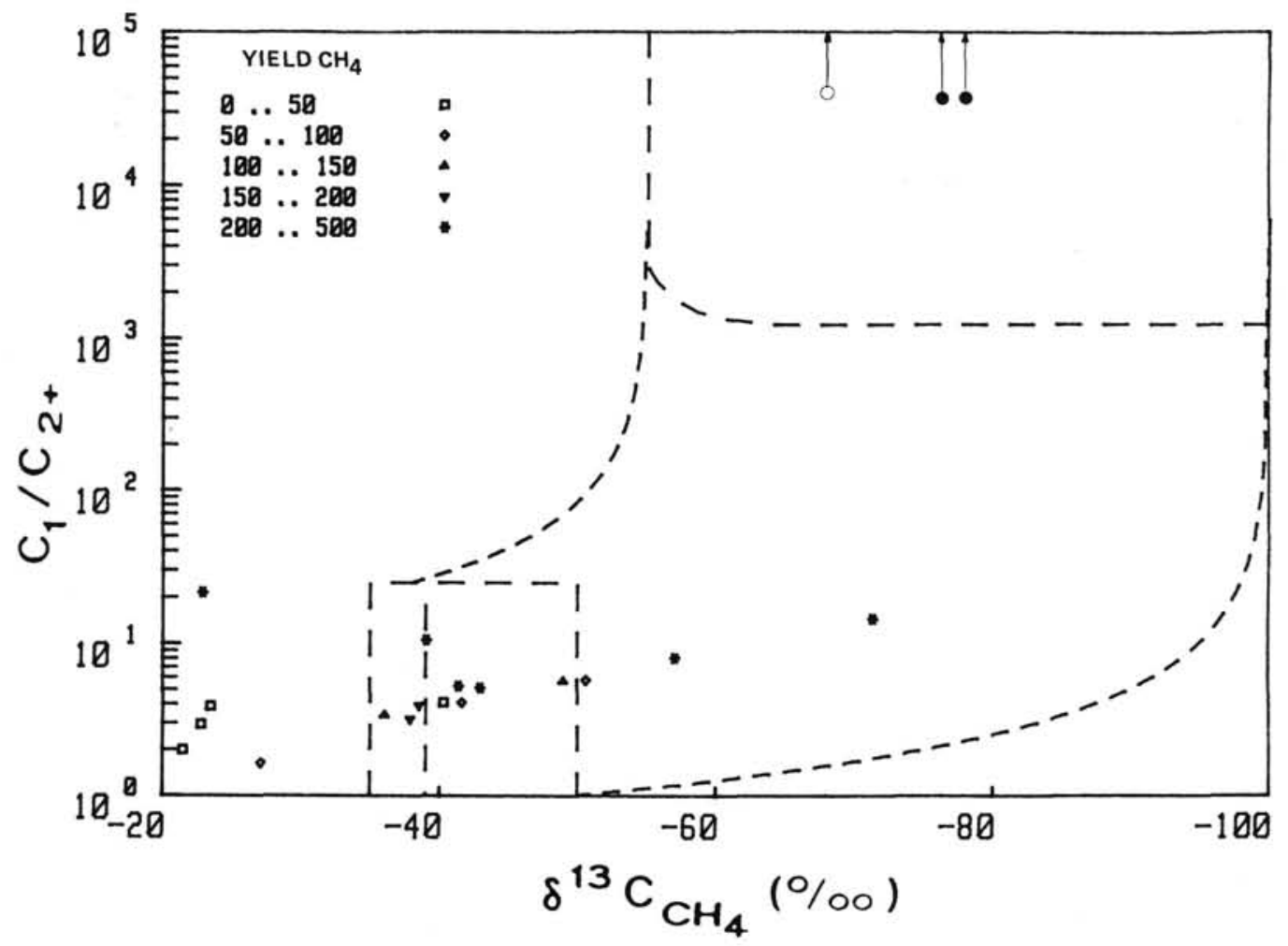

Figure 3. Hydrocarbon gas composition plot of $\delta^{13} \mathrm{C}_{\mathrm{CH}_{4}}$ vs. $\mathrm{C}_{1} / \mathrm{C}_{2+}$ at Sites 642,643 , and 644 . The samples are differentiated into five groups (symbols) based on methane yield. The open circle is a headspace sample and the two closed circles are Vacutainer samples. 


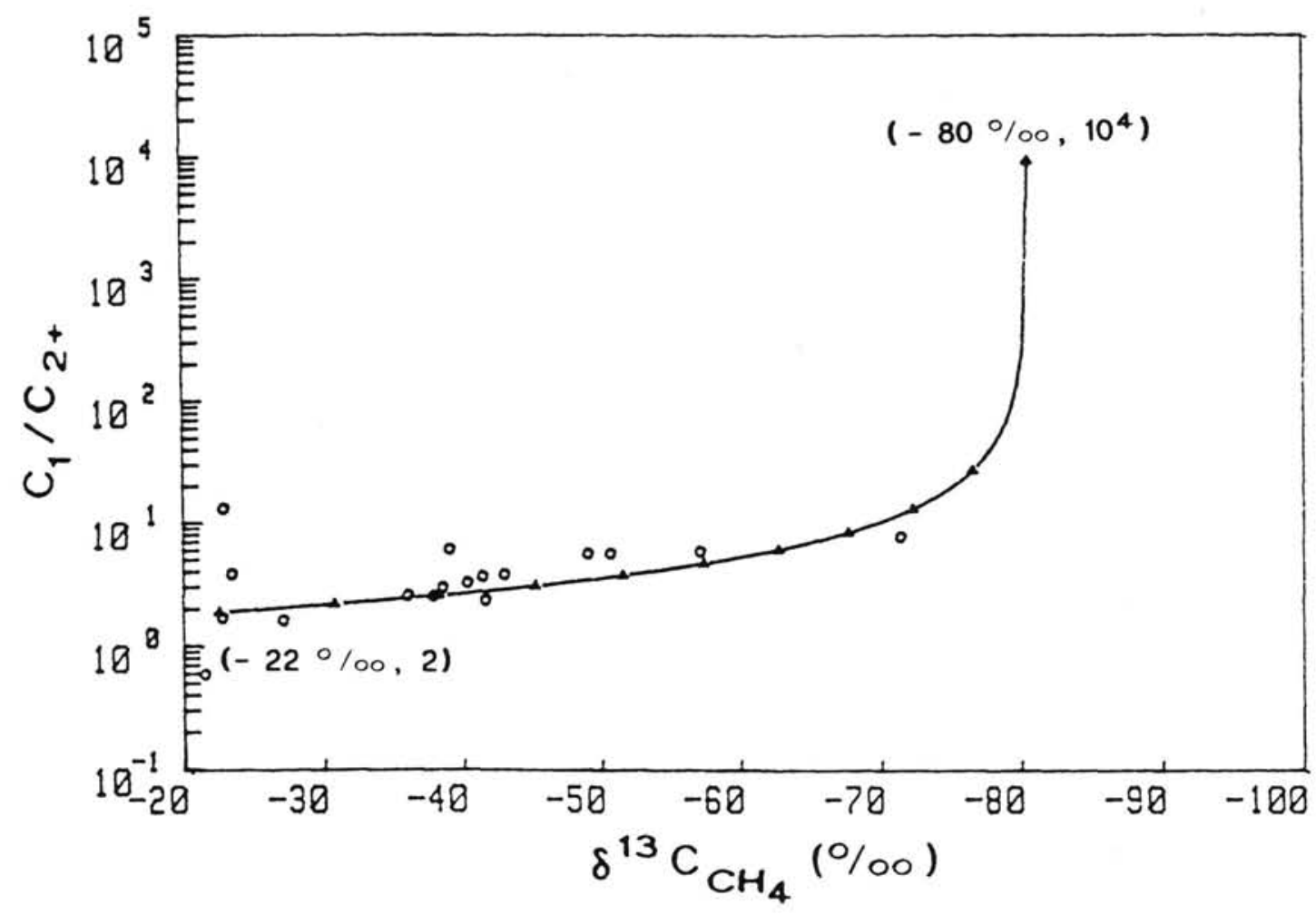

Figure 4. Calculated mixing line of diagenetic/background gas $\left(\mathrm{C}_{1} / \mathrm{C}_{2+}=2.0, \delta^{13} \mathrm{C}_{\mathrm{CH}_{4}}=-22 \%\right.$ ) and biogenic gas $\left(\mathrm{C}_{1} / \mathrm{C}_{2+}=10^{4}, \delta^{13} \mathrm{C}_{\mathrm{CH}_{4}}=-80 \%\right)$. Triangles mark the fraction of the two end members on the mixing line at $10 \%$ intervals. The total hydrocarbon gas values from Sites 642,643 , and 644 are plotted as open circles.

Hydrocarbon gas compositions and concentrations at Holes $642 \mathrm{~B}, 642 \mathrm{D}$, and $643 \mathrm{~A}$ are, for the most part, representative of background gases, possibly generated by diagenetic reactions. These sites are directly over, and at the foot of the outer Vøring Plateau, respectively, where the hydrocarbon generation potential is expected to be poor. The relative ${ }^{13} \mathrm{C}$ enrichments in the methane and ethane are distinctive for this gas type.

Biogenic gas (predominantly methane) is the primary hydrocarbon gas in headspace analyses of sediments from the inner Vøring Basin (Hole 644A). Removal of most of this free gas fraction (the physical location of this gas) permits the sorbed gas signature to appear. This latter gas type is probably a mixture of diagenetic and biogenic gas types. However, the available data could neither unequivocally refute nor confirm the existence of thermogenic hydrocarbons in certain samples from the inner Vøring Basin.

The interpretation of hydrocarbon gas origins for sediment samples with very low gas concentrations is often uncertain or even speculative, and strongly depends on sample quality. Once gas contents increase to levels above background, the classification of the sediment gases can be made with greater confidence.

\section{ACKNOWLEDGMENTS}

We would like to thank the crew and shipboard scientists, especially Keith Kvenvolden and Tom McDonald, for obtaining the samples for this investigation. In addition the help of the ODP staff members, in particular Elliott Taylor, is appreciated. Numerous helpful remarks were also provided by Drs. D. Rice and B. Bernard. Our work is funded by B.M.F.T. Grant No. $6237 \mathrm{~A}$ in Germany.

\section{REFERENCES}

Bernard, B. B., 1980. Light hydrocarbons in marine sediments [Ph.D. dissert.]. Texas A \& M University, College Station.
Bernard, B. B., Brooks, J. M., and Sackett, W. M., 1978. Light hydrocarbons in recent Texas continental shelf and slope sediments. $J$. Geophys. Res. 83:4053-4051.

Erdman, J. G., and Schorno, K. S., 1976. Geochemistry of carbon, DSDP Leg 38. In Talwani, M., and Udintsev, G., et al., Init. Repts. DSDP, 38:791-799.

Faber, E., and Stahl, W., 1984. Geochemical surface exploration of hydrocarbons in the North Sea. AAPG Bull., 68:363-386.

Kvenvolden, K. A., and Redden, G. D., 1980. Hydrocarbon gas in sediment from the shelf, slope, and basin of the Bering Sea. Geochim et Cosmochim Acta, 44:1145-1150.

Morris, D. A., 1976. Organic diagenesis of Miocene sediments from Site 341, Vøring Plateau, Norway. In Talwani, M., and Udintsev, G., et al., Init. Repts. DSDP, 38:809-814.

Schoell, M., 1980. The hydrogen and carbon isotopic composition of methane from natural gases of various origins. Geochim. Cosmochim. Acta, 44:649-661.

Whiticar, M. J., and Faber, E. 1986. Methane oxidation in sediment and water column environments-isotope evidence. In Leythaeuser, D., and Rullkötter, J., Eds., Advances in Organic Geochemistry. Org. Geochem. 10, 759-768.

Whiticar, M. J., and Faber, E., 1987. Carbon and hydrogen isotopes in gas samples from leg 95, holes 603D and 613. In Poag, C. W., Watts, A. B., et al., Init. Repts. DSDP, 95: Washington (U.S. Govt. Printing Office), 647-650.

Whiticar, M. J., Faber, E., and Schoell, M., 1986. Biogenic methane formation in marine and freshwater environments: $\mathrm{CO}_{2}$ reduction vs. acetate fermentation-isotope evidence. Geochim. Cosmochim. Acta. 50, 693-709.

Date of initial receipt: 27 March 1987

Date of acceptance: 24 February 1988 Ms 104B-127 